Original Article

\title{
Prevalence and diversity of ectoparasites in Wild Rock Pigeon (Columba livia) in Punjab region, Pakistan
}

\author{
Prevalência e diversidade de ectoparasitas em Wild Rock Pigeon (Columba livia) na \\ região de Punjab, Paquistão
}

\author{
M. Tayyuba ${ }^{\mathrm{a}, \mathrm{b}}$, S. Alia,b* (D), A. Javid ${ }^{\mathrm{b}}$ (1) and M. Imran (D) \\ aUniversity of Veterinary and Animal Sciences, Department of Wildlife and Ecology, Discipline of Zoology, Wildlife Epidemiology and \\ Molecular Microbiology Laboratory (One Health Research Group), Lahore, Ravi Campus, Pattoki, Pakistan \\ bUniversity of Veterinary and Animal Sciences, Department of Wildlife and Ecology, Lahore, Ravi Campus, Pattoki, Pakistan \\ cUniversity of Veterinary and Animal Sciences, Institute of Biochemistry and Biotechnology, Lahore, Pakistan
}

\begin{abstract}
The current study was carried out to estimate the prevalence and diversity of ectoparasites in rock pigeons in different regions of Punjab, Pakistan. A total of 120 birds were captured from March 2017 to February 2019. The ectoparasites were collected by standard procedures and preserved in $70 \%$ ethanol containing one drop of glycerin. Data related to age, health status, sex, type of area, sampling location and season were collected using a standardized form. Ectoparasites were identified based on morphological characteristics by using identification keys. Ninety-six (80\%) birds were infested with ectoparasites. A total of seven families and thirteen species of different ectoparasites were observed. Mainly, seven species of lice, two species of flies, one species of tick and three species of mites were recovered from infested birds. The female pigeons were more often infested (89.02\%) than male pigeons (60.52\%). The prevalence was found higher during summer (100\%) as compared to other seasons. The infestation rate was higher in Industrial area (97.50\%) as compared to other regions. The highest prevalence of ectoparasites $(100 \%)$ was recorded from Sargodha district. There was significant $(\mathrm{P}<0.05)$ variation among number of ectoparasites on wing, chest, tail and neck within age groups, seasons and ecological zones. The occurrence of parasites in relation to area, age, health status, sex and season were significant. The infestation rate of parasites in rock pigeon is high in different districts of Punjab. It is recommended that these wild birds infested with multiple species of ectoparasites could be the potential source of infestations in domesticated birds if they come in contact with them. The contact of domesticated birds should be prevented from wild birds to minimize the chance of cross species transmission of ectoparasites.
\end{abstract}

Keywords: lice, flies, ticks, mites, rock pigeon, prevalence, ecological zones.

\begin{abstract}
Resumo
O presente estudo foi realizado para estimar a prevalência e diversidade de ectoparasitas em pombos-das-rochas em diferentes regiões de Punjab, Paquistão. Um total de 120 aves foram capturadas de março de 2017 a fevereiro de 2019. Os ectoparasitas foram coletados por procedimentos padrão e preservados em etanol $70 \%$ contendo uma gota de glicerina. Os dados relativos à idade, estado de saúde, sexo, tipo de área, local de amostragem e época do ano foram coletados em formulário padronizado. Os ectoparasitas foram identificados com base nas características morfológicas por meio de chaves de identificação. Noventa e seis (80\%) aves estavam infestadas com ectoparasitas. Um total de sete famílias e treze espécies de diferentes ectoparasitas foram observados. Principalmente, sete espécies de piolhos, duas espécies de moscas, uma espécie de carrapato e três espécies de ácaros foram recuperadas de aves infestadas. Os pombos fêmeas foram infestados mais frequentemente $(89,02 \%)$ do que os pombos machos $(60,52 \%)$. A prevalência encontrada foi maior no verão (100\%) em comparação com as outras estações. A taxa de infestação foi maior na área Industrial (97,50\%) em relação às demais regiões. A maior prevalência de ectoparasitas (100\%) foi registrada no distrito de Sargodha. Houve variação significativa $(P<0,05)$ entre o número de ectoparasitas na asa, tórax, cauda e pescoço dentro das faixas etárias, estações do ano e zonas ecológicas. A ocorrência de parasitas em relação à área, idade, estado de saúde, sexo e estação do ano foi significativa. A taxa de infestação de parasitas em pombo-correio é alta em diferentes distritos de Punjab. Recomenda-se que essas aves selvagens infestadas com várias espécies de ectoparasitas possam ser a fonte potencial de infestações em aves domesticadas se entrarem em contato com elas. $\mathrm{O}$ contato de aves domesticadas deve ser evitado com aves selvagens para minimizar a chance de transmissão cruzada de ectoparasitas.
\end{abstract}

Palavras-chave: piolhos, moscas, carrapatos, ácaros, pombo-da-rocha, prevalência, zonas ecológicas.

*e-mail: shahzad.ali@uvas.edu.pk

Received: December 22, 2020 - Accepted: February 10, 2021 


\section{Introduction}

Rock Pigeon (Columba livia) belonging to the order Columbiformes can be found virtually in every geographical region of the world (even in city and town) except for the poles. In Pakistan pigeons are the most prevalent and readily observable in all ecological regions of the country (Jezkova and Wiens, 2017). The feral pigeons have been living side by side with human habitation for thousands of years and are used as a source of food, sports, religious purpose, and experimental aims like some other animal species (Adang et al., 2008).

Pigeon may harbor a great variety of ectoparasites broadly affecting their life history. The parasitological findings not only play a significant role in approximation of health status of the birds but are also useful indicators to monitor the climatic changes favoring the parasitic host, load and other factors such as population density, breeding success, scanty of food and inter and intra-specific competitions for resources. These parasites such as ticks, mites, lice and fleas have been reported to show a variety of physiological, anatomical and morphological adaptations to enhance their living style and existence on their specific host (Musa et al., 2012).

These parasites as vectors are also responsible for feeding on host skin, sucking blood and cause irritation, skin damage, restlessness, illness, restricted growth, hyper local inflammation, consuming tissue fluid, loss of weights, reduction of egg production, intense itching and sleepless problems in birds and contribute to a depressed situation of health, as a result of their bites with sucking and piercing mouthparts (Bush et al., 2019).

The infestation of ectoparasites, e.g. ticks (Argas reflexus), lice (Campanulotes compar, Columbicola columbae, Colpocephalum turbinatum, Columbicola tschulyschman, Coloceras damicorne, Hohorstiella (H.) lata), mites (Psoroptes sp, Dermanyssus gallinae, Falculifer rostratus) and fly (Pseudolynchia canariensis) in domesticated and wild pigeon has been reported in most of the neighboring countries of Pakistan including Bangladesh, India, Iran (Musa et al., 2011; Saikia et al., 2017; Chaechi-Nosrati et al., 2018; Mehmood et al., 2019). Similar findings of prevalence of ectoparasites of pigeon have been reported from Iraq (i.e. Columbicola columbae, H. lata, Campanulotes compar and Columbicola tschulyschman) (Abdullah et al., 2018) and Nigeria (i.e. Columbicola columbae and Colpocephalum turbinatum) (Laku et al., 2018).

However, only two studies have reported the prevalence of pigeon's ectoparasites in Punjab and Sindh provinces of Pakistan. Colpocephalum turbinatum and Columbicola columbae have been reported in the south-east Sargodha region of Punjab province (Ahmed et al., 2017). Columbicola columbae and Menopongallinae were recorded in domestic pigeons of Umerkot region of Sindh province, Pakistan (Arijo et al., 2018).

Considering the limited availability of published data of ectoparasites of rock pigeons in Pakistan, additional data is needed. Therefore, this research was planned to estimate the occurrence of ectoparasites of rock pigeon and their diversity in different regions of Punjab, Pakistan.

\section{Materials and Methods}

\subsection{Study location}

Ten districts were randomly selected from three geographical zones, South (Bahawalpur, DG Khan and Multan), Central (Faisalabad, Lahore and Sialkot) and North zones (Khushab, Mianwali, Rawalpindi and Sargodha) of Punjab, Pakistan (Figure 1)

Punjab province is located at an elevation of 286 meters above the sea level bordered between latitude $31.1704^{\circ} \mathrm{N}$

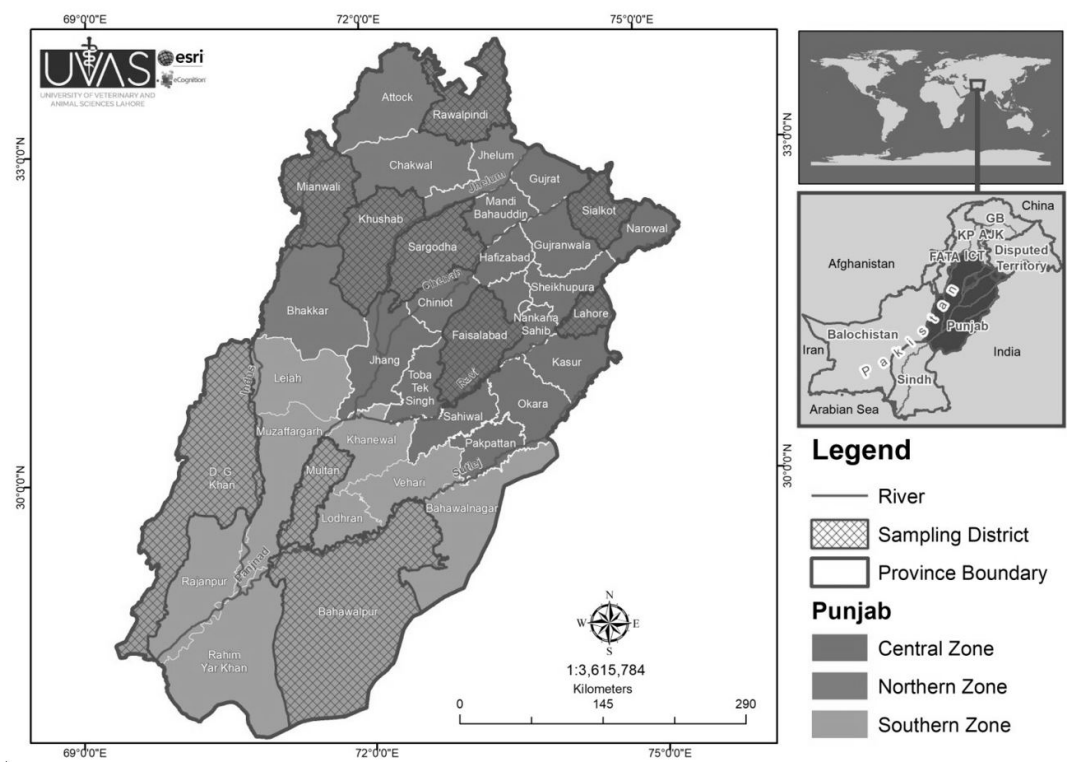

Figure 1. Three geographical zones and ten districts were selected south zone Punjab (Bahawalpur, DG Khan and Multan), central zones Punjab (Faisalabad, Lahore, and Sialkot) and north zones (Khushab, Mianwali, Rawalpindi and Sargodha) of Punjab, Pakistan. 
and longitude $72.7097^{\circ} \mathrm{E}$. It is located in the temperate zone and climate is characterized by arid with hot summer and a mild or cold wintry temperature. These variations can easily be found between different ecological locations in Punjab (Chaudhry, 2017).

\subsection{Study design}

A multi-stage sampling strategy was used for birds sampling from ten districts of Punjab Province, Pakistan, from March, 2017 to February 2019. Four sites were selected from each district for birds sampling. Sites selected for capturing of rock pigeon were urban area, agriculture area, industrial area and rural area. Three birds captured using Mist nets from each site resulted in twelve samples from each district, with a total of 120 birds captured from ten districts.

\subsection{Collection and identification of ectoparasites}

The live birds were examined for collection and quantification of ectoparasites load by following the methods described in previously (Walther and Clayton, 1997).

\subsection{Data collection}

Data related to age (young/adults), health status (healthy/weak), sex (male/female), area (urban, agriculture, industrial, rural), sampling sites (districts) and season (summer, pre-monsoon, post-monsoon and winter) of sampling were collected using a standardized form.

\subsection{Identification of ectoparasites}

The chewing lice and soft ticks were mounted permanently for identification by relaxing and dehydrating them through graded series of ethanol from 30-90\% and absolute ethanol, fixed with xylol and clove oil before mounting in Canada balsam. The mites were mounted directly in Hoyer's medium and were then sealed using a cover slip with white nail polish. From each bird the lice were placed in a tube have $70 \%$ ethanol, fixed in permanent slides followed by their identification based on morphological characteristics by using identification keys (Tendeiro, 1969; Price et al., 2003; Naz et al., 2012) under stereomicroscope ( $\times$ 400: Leica DM8000 M).

\subsection{Statistical analysis}

The prevalence and intensity were described as define in previous study (Margolis et al., 1982). The mean intensity was calculated in percentage using below mentioned Equation 1.

Mean Intensity $=\frac{\text { Total No. of each ectoparasites species collected }}{\text { Total No. of birds infested by each ectoparasites species }}$

The associations between parasitic prevalence and different factors (i.e. season, area, age, health status, sex) were determined using Chi-square test with the help of SPSS Version 21.0. The level of significance was $\mathrm{p} \leq 0.05$. Analysis of Variance was applied through F-test to determine any possible significance between single and mixed infestation.

\section{Results}

Out of 120 rock pigeons examined, 96 (80\%) were infested with ectoparasites. Seven families and thirteen species of ectoparasites were recognized, which were included of 8 species of lice; 2 species of fly, 1 species of tick and 3 species of mites (Table 1 ). The ectoparasites were collected from various parts of the body of rock pigeons. The lice species, H. lata, C. turbinatum, C. tschulyschman, Coloceras damicorne, C. columbae, and C. bidentatus were recovered from head, neck, quill feathers of wings, tail, rump, nap, beneath shafts and rachis while one species of fly $P$. canariensis was found from the down and counter feathers of the skin. Three mite's species i.e. D. gallinae, F. rostratus and Psoroptes were found from secondary shafts, legs and down feathers while ticks from legs and shaft feathers.

The rock pigeons had higher prevalence of single infestation (48.33\%) compared with double infestation (26.66\%), triple $(4.16 \%)$ and quadruple $(0.833 \%)$, whilst $24(20 \%)$ of the birds were uninfected (Table 2 ). There was a significant $(\mathrm{P}=.001)$ difference between seasonal patterns of the prevalence of parasites during different seasons of the study period. The highest prevalence of ectoparasites was found during summer season (100\%), followed by post monsoon (81.39\%), winter (71.42\%) and pre-monsoon (68.42\%) from Punjab (Table 3 ). It was observed that captured rock pigeons were 100\% infested from district Sargodha (north Punjab zones). However, lowest prevalence of ectoparasites was recorded from Bahawalpur (5.83\%) (Table 4). A remarkable variation was found among different epidemiological factors associated with the prevalence of ectoparasites. A significant $(\mathrm{P}<0.05)$ difference was observed between the prevalence of ectoparasites found in industrial areas (97.50\%) and rural areas (22.22\%) (Table 5). The highest prevalence of ectoparasites was found in adults birds (83.60\%) as compared to young ones (76.27\%). The weak birds were significantly $(\mathrm{P}<0.05)$ more infested as compared to healthy birds. The gender-wise examination of 120 birds revealed that females were more often infested (89.02\%) when compared to males (86.84\%) (Table 5). The map of agro-ecological regions is showing variations in the prevalence of ectoparasites in Punjab. The prevalence of ectoparasites in three zones of Punjab are as follows; lowest intensity varied (2.963-6.956\%) and (6.957-8.788\%) from Central Punjab; the medium infestation rate is represented in (8.79-10.41\%) and (10.42-12.41\%) from South Punjab the highest intensity (12.42-16.59\%) is presented from North Punjab (Figure 2). Non-significant variance in the infestation of ectoparasites was observed in neck area among health status and seasons. The parasitic infestation variance on neck region showed the statistically significant difference between numbers of parasite with different age, sampling areas, as well as in the sex (Table 6).

The comparison among different parasites prevalence on the wings showed there is significant difference between age and sex of rock pigeons while comparison of different sampling areas, health status and seasons for the parasites on the wings was non-significance (Table 6). The maximum number of ectoparasites picked from chest area was 13 . Majority of the districts did not have any variation on 
Table 1. Prevalence and prediction sites of ectoparasites infestation of rock pigeon in Punjab.

\begin{tabular}{|c|c|c|c|c|c|}
\hline Family/Parasite name & Site of recovery & $\begin{array}{c}\text { No. of } \\
\text { columbids } \\
\text { infested }\end{array}$ & $\begin{array}{c}\text { Prevalence } \\
(\%)\end{array}$ & $\begin{array}{c}\text { Total number } \\
\text { of ectoparasites } \\
(\%) \\
\end{array}$ & Intensity \\
\hline \multicolumn{6}{|l|}{ Menoponidae (Lice) } \\
\hline Campanulotes compar & \multirow{5}{*}{$\begin{array}{l}\text { Head, neck, quill } \\
\text { feathers of wings, tail, } \\
\text { rump and nap }\end{array}$} & 43 & 35.83 & 958 & 22.27 \\
\hline Coloceras damicorne & & 47 & 39.16 & 265 & 5.63 \\
\hline Columbicola tschulyschman & & 39 & 32.50 & 789 & 20.23 \\
\hline Colpocephalum turbinatum & & 25 & 20.83 & 510 & 20.4 \\
\hline Hohorstiella lata & & 41 & 34.16 & 785 & 19.07 \\
\hline \multicolumn{6}{|l|}{ Philopteridae (Lice) } \\
\hline Columbicola columbae & Body, head, neck & 83 & 69.16 & 1935 & 23.31 \\
\hline Bonomiella columbae & Feathers of wings & 43 & 35.83 & 170 & 3.25 \\
\hline \multicolumn{6}{|c|}{ Ceratophyllus columbae (Fly) } \\
\hline Ceratophyllus columbae & Barbules, barb & 23 & 19.16 & 256 & 11.13 \\
\hline \multicolumn{6}{|l|}{ Hippoboscidae (Fly) } \\
\hline Pseudolynchia canariensis & $\begin{array}{l}\text { Down and counter } \\
\text { feathers of body }\end{array}$ & 55 & 45.83 & 431 & 7.83 \\
\hline \multicolumn{6}{|l|}{ Argasidae (Tick) } \\
\hline Argus reflexus & $\begin{array}{l}\text { Legs and shaft } \\
\text { feathers }\end{array}$ & 04 & 3.33 & 11 & 2.75 \\
\hline \multicolumn{6}{|l|}{ Dermanysidae (Mite) } \\
\hline Dermanyssus gallinae & Secondary shafts & 02 & 1.66 & 09 & 4.5 \\
\hline \multicolumn{6}{|l|}{ Falculiferidae (Mite) } \\
\hline Falculifer rostratus & Legs, shafts & 05 & 4.16 & 17 & 3.4 \\
\hline \multicolumn{6}{|l|}{ Psoroptidae (Mite) } \\
\hline Psoroptes sp. & Down feathers & 07 & 5.83 & 13 & 1.85 \\
\hline
\end{tabular}

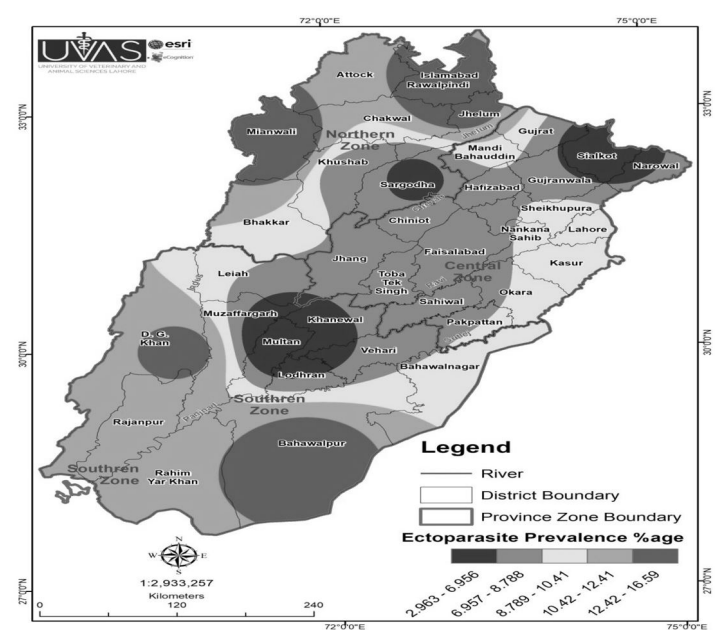

Figure 2. The map of agro-ecological regions showing the prevalence of ectoparasites. The prevalence of ectoparasites in three zones of Punjab as follows such as lowest intensity in Central Punjab, Medium intensity from South Punjab and highest intensity from North Punjab.

comparison from different sampling sites among ecological zones. A significant difference was observable in results between the health status and seasons, and number of parasites on chest regions. Moreover, sex and age were not significance (Table 6).
The non-significant association in results was observed in the prevalence in tail of bird and sex. The substantial difference of variance ( $F$ value of parasites) in the tail showed that there was a substantial variation among the total quantity of ectoparasites on tail with in age, sampling sites, seasons and health stratus (Table 6). The non-significant association in results was observed on the parasitic infestation in the rump and nape feather of rock pigeon between age and sex as compared to sampling sites. The significant difference of $F$ value of parasites on rump and nape feather of the rock pigeons was clearly an evidence of difference among the number of ectoparasites on tail with in sampling sites, seasons and health stratus (Table 6).

\section{Discussion}

The total infestation rate of ectoparasites in rock pigeon was 80\% (96/120) in our study. However, relatively higher (90.5\%) prevalence was recorded from Sargodha region of Punjab, Pakistan (Arijo et al., 2018). Furthermore, the difference in occurrence of parasites in rock pigeon has been reported from different parts of the world (Adang et al., 2008; Jahantigh et al., 2016; Rani and Rajakumari, 2020).

During the current study seven species of chewing lice were recognized from rock pigeons from three ecological zones of Punjab (Table 1). Similar observation of high infestation of rock pigeon with multiple species 
Table 2. Frequency distribution of single and mixed ectoparasites infestation on rock pigeons.

\begin{tabular}{|c|c|c|c|}
\hline \multirow{2}{*}{ Infection type } & \multicolumn{3}{|c|}{ Frequency of occurrence } \\
\hline & Parasite & Total & (\%) \\
\hline None & & 24 & 20.00 \\
\hline \multirow[t]{13}{*}{ Single } & Argus reflexus & 04 & \\
\hline & Colpocephalum turbinatum & 04 & \\
\hline & Ceratophyllus columbae & 02 & \\
\hline & Menacanthus straminus & 07 & \\
\hline & Columbicola columbae & 13 & \\
\hline & Dermanyssus gallinae & 02 & \\
\hline & Falculifer rostratus & 05 & \\
\hline & Hohorstiella lata & 07 & \\
\hline & Campanulotes compar & 03 & \\
\hline & Coloceras damicorne & 04 & \\
\hline & Pseudolynchia canariensis & 02 & \\
\hline & Psoroptes & 05 & \\
\hline & Sub-total & 58 & 48.33 \\
\hline \multirow[t]{5}{*}{ Double } & Campanulotes compar + Psoroptes & 03 & \\
\hline & C. columbae + Coloceras damicorne & 15 & \\
\hline & Columbicola columbae+ Argus reflexus & 05 & \\
\hline & Pseudolynchia canariensis $+C$. columbae & 09 & \\
\hline & Sub-total & 32 & 26.66 \\
\hline \multirow[t]{3}{*}{ Triple } & P. canariensis $+C$. tschulyschman $+D$. gallinae & 03 & \\
\hline & C. columbae + A. reflexus sp. + Psoroptes & 02 & \\
\hline & Sub-total & 05 & 4.16 \\
\hline \multirow[t]{2}{*}{ Quadruple } & C. columbae $+P$. canariensis $+C$. tschulyschman sp. $+D$. gallinae & 01 & \\
\hline & Sub-total & 01 & 0.833 \\
\hline
\end{tabular}

Table 3. Seasonal prevalence of ectoparasites in rock pigeons.

\begin{tabular}{lcccccc}
\hline \multicolumn{1}{c}{ Seasonality } & Total $(\mathbf{n})$ & Infested $(\mathbf{n})$ & $\begin{array}{c}\text { Prevalence } \\
\text { (\%) }\end{array}$ & $\begin{array}{c}\text { Total number } \\
\text { of parasites } \\
\text { collected }\end{array}$ & Intensity & $\begin{array}{c}\text { Statistical analysis } \\
\text { (Chi-square analysis) }\end{array}$ \\
\hline Summer & 25 & 25 & 100 & 2275 & 91 & x2=17.13, d.f=3, P=.005 \\
Pre-Monsoon & 38 & 26 & 68.42 & 1551 & 40.5 & \\
Post-Monsoon & 43 & 35 & 81.39 & 1858 & 43.20 \\
Winter & 14 & 10 & 71.42 & 1368 & 97.71 & \\
\hline
\end{tabular}

of lice was reported from Karachi city of Sindh province of Pakistan (Naz et al., 2012). However, only 2 species of lice i.e. C. turbinatum and C. columbae were reported from South-east region in Punjab, Pakistan (Ahmed et al., 2017). From neighboring and other countries, the prevalence of C. columbae in domestic pigeons in Tirunelveli district, India was $80.95 \%$ (Rani and Rajakumari, 2020) and the prevalence of $B$. columbae in domestic pigeons in Poltava region from Ukarine was 100\% (Kolomak and Kruchynenko, 2017).

In our study, $19.16 \%$ birds were infested with one spices of fly C. columbae and $45.83 \%$ of birds were infested with one species of fly P. canariensis. Variation in prevalence of $P$. canariensis has been observed in pigeons of neighboring countries. The prevalence rate of $P$. canariensis varied from $16.1 \%$ to $73.3 \%$ in free living domestic pigeons and wild rock pigeons in different region of Iran (Chaechi-Nosrati et al., 2018; Rezaei et al., 2016). Similar observations were reported from India, where rate of prevalence with $P$. canariensis in free living and domestic pigeons were reported as $36.67 \%$, dipteran fly P. canariensis (65\%) in Kamrup districts (rural and metro) of Assam, Jammu 61.90\% and in Tirunelveli region of India 
Table 4. Prevalence of ectoparasites in wild rock pigeons in different districts of the Punjab province.

\begin{tabular}{|c|c|c|c|c|c|}
\hline Districts & Birds examined & $\begin{array}{l}\text { No. of positive } \\
\text { birds }\end{array}$ & Prevalence (\%) & $\begin{array}{c}\text { No. of } \\
\text { ectoparasites }\end{array}$ & Intensity \\
\hline Bahawalpur & 12 & 7 & 58.3 & 1117 & 159.75 \\
\hline DG Khan & 12 & 10 & 83.3 & 1025 & 102.5 \\
\hline Multan & 12 & 8 & 66.6 & 225 & 28.13 \\
\hline Faisalabad & 12 & 9 & 75 & 605 & 67.22 \\
\hline Lahore & 12 & 9 & 75 & 758 & 84.22 \\
\hline Sialkot & 12 & 10 & 83.3 & 395 & 39.5 \\
\hline Mianwali & 12 & 10 & 83.3 & 1260 & 126.00 \\
\hline Rawalpindi & 12 & 11 & 91.6 & 1210 & 121.0 \\
\hline Khushab & 12 & 10 & 83.3 & 560 & 56.00 \\
\hline Sargodha & 12 & 12 & 100 & 435 & 36.25 \\
\hline
\end{tabular}

Table 5. Association of epidemiological factors with the prevalence of parasites in wild pigeons.

\begin{tabular}{lccccc}
\hline \multicolumn{1}{c}{ Variables } & Factors & Examined & Infested & Prevalence $\%$ & Chi square \\
\hline Area & Industrial Area & 40 & 39 & 97.50 & $\chi 2=20.20$, d.f $=3, \mathrm{P}=0.01$ \\
& Urban Area & 34 & 30 & 88.23 & \\
& Agricultural Area & 37 & 25 & 67.56 & \\
Age & Rural Area & 09 & 02 & 22.22 & \\
& Adult & 61 & 51 & 83.60 & $\chi 2=0.033$, d.f $=1, \mathrm{P}=0.031$ \\
Health status & Young & 59 & 45 & 76.27 & \\
& Healthy & 118 & 94 & 79.66 & $\chi 2=112.13$, d.f $=1, \mathrm{P}=0.04$ \\
Sex & Weak & 02 & 02 & 100.00 & \\
& Male & 38 & 23 & 60.52 & $\chi 2=16.13$, d.f= $1, \mathrm{P}=0.05$ \\
\end{tabular}

(Mehmood et al., 2019; Bora, 2017; Rani and Rajakumari, 2020). In conflicting to our outcomes, a comparatively low infestation of $P$. canariensis was reported from Tripoli province, Libya (1.00\%) and Zaria district, Nigeria (2.5\%) in pigeons (Adang et al., 2008; Alkharigy et al., 2018). The possible reason for these variations in parasite infestation might be because of climate variations found in different geographical regions.

Only one soft tick species Argus reflexs belonging to family Argasidae was found in the different ecological regions of Punjab. There is very limited data available on prevalence of ticks in rock pigeons from world. A prevalence of A. reflexus in pigeons was reported in Iran (Jahantigh et al., 2016). Three species of mites Dermanyssus gallinae (1.66\%), Falculifer rostratus (4.16\%) and Psoroptes (5.83\%) was observed from Punjab. While the incidence of Dermanyssus gallinae and Falculifer rostratus in wild rock pigeons in Lahijan city, Guilan, Iran was 3.3\% and $31.6 \%$, respectively (Chaechi-Nosrati et al., 2018). The red mite D. gallinae (20\%) from domestic pigeons observed from Kamrup districts (rural and metro) of Assam, India (Bora, 2017). Furthermore, high prevalences of mites; Dermanyssus gallinae (39.26\%), Falculifer rostratus (25.30\%) and Psoroptes (21.21\%) were reported in wild rock pigeons in Algiers Sahel, Algeria (Djelmoudi et al., 2017).

The frequency distribution of single and mixed ectoparasites occurrence (80\%) were recorded from south, central and north zones in Punjab. Our result was similar to Zaria, Nigeria, in which domestic pigeons had higher single infestation (30.8\%) follow by double (39.6\%) and triple infestation (2.9\%) and no statistically significant difference was apparent between infestations (Adang et al., 2008). The prevalence of ectoparasites diversity was significant higher during the warmest seasons, moderate in winter seasons and lowest in pre and post monsoon in present study. These observations were in line to neighboring country India (Bora, 2017). Our results, therefore, support the findings from southern Manitoba, Canada that C. columbae presenting greater seasonal variations for all ecological zones including $H$. lata was most abundant during the cold months (Galloway and Lamb, 2015). The higher temperature in the warm season might be one of the possible reasons for the greater prevalence of ectoparasites in rock pigeons of Pakistan.

A significant difference $(\mathrm{p}<0.05)$ was detected among prevalence of ectoparasites collected from industrial 
Table 6. Association of sex, sampling area, sex, health status and season with body-parts of rock Pigeon.

\begin{tabular}{|c|c|c|c|c|c|c|}
\hline Factor & Trait & $\begin{array}{l}\text { Degree of } \\
\text { Freedom }\end{array}$ & Sum of square & $\begin{array}{c}\text { Mean Square } \\
\text { value }\end{array}$ & F-value & Significance \\
\hline \multirow[t]{5}{*}{ Neck feather } & Age & 1 & 1.561 & 0.260 & 1.034 & 0.02 \\
\hline & Sampling area & 3 & 5.622 & 0.937 & 1.063 & 0.03 \\
\hline & Sex & 1 & 0.941 & 0.157 & 0.708 & 0.05 \\
\hline & Health status & 1 & 0.058 & 0.10 & 0.568 & 0.07 \\
\hline & Seasons & 3 & 3.149 & 0.525 & 0.582 & 0.74 \\
\hline \multirow[t]{5}{*}{ Wing feather } & Age & 1 & 2.650 & 0.379 & 1.551 & 0.01 \\
\hline & Sampling area & 3 & 4.427 & 0.632 & 0.703 & 0.06 \\
\hline & Sex & 1 & 1.841 & 0.263 & 1.221 & 0.02 \\
\hline & Health status & 1 & 0.212 & 0.030 & 1.934 & 0.07 \\
\hline & Seasons & 3 & 10.854 & 1.551 & 1.845 & 0.08 \\
\hline \multirow[t]{5}{*}{ Chest feather } & Age & 1 & 1.209 & 1.73 & 0.672 & 0.06 \\
\hline & Sampling area & 3 & 7.422 & 1.060 & 1.215 & 0.30 \\
\hline & Sex & 1 & 0.939 & 0.134 & 0.600 & 0.07 \\
\hline & Health status & 1 & 0.100 & 0.014 & 0.857 & 0.05 \\
\hline & Seasons & 3 & 6.867 & 0.981 & 1.120 & 0.03 \\
\hline \multirow[t]{5}{*}{ Tail feather } & Age & 1 & 2.252 & 0.375 & 1.529 & 0.01 \\
\hline & Sampling area & 3 & 11.458 & 1.910 & 2.302 & 0.039 \\
\hline & Sex & 1 & 0.912 & 0.152 & 0.686 & 0.06 \\
\hline & Health status & 1 & 0.147 & 0.024 & 1.517 & 0.01 \\
\hline & Seasons & 3 & 5.601 & 0.933 & 1.061 & 0.03 \\
\hline \multirow{5}{*}{$\begin{array}{l}\text { Rump and } \\
\text { nape feather }\end{array}$} & Age & 1 & 0.006 & 0.006 & 0.23 & 0.08 \\
\hline & Sampling area & 3 & 2.194 & 2.194 & 2.514 & 0.01 \\
\hline & Sex & 1 & 0.047 & 0.047 & 0.212 & 0.06 \\
\hline & Health status & 1 & 0.024 & 0.024 & 1.446 & 0.02 \\
\hline & Seasons & 3 & 1.640 & 1.640 & 1.873 & 0.01 \\
\hline
\end{tabular}

to rural areas of Punjab. Our results were in line with a study conducted in Sargodha area of south-east of Punjab (Ahmed et al., 2017). The higher infestation rate in chewing lice recorded from industrial, town councils and urban zones could be a result of high adaptation with human associated regions of rock pigeons accomplished areas for breeding, food and other sources (Nylin et al., 2018)

In present study the adult birds were more often infested with ectoparasites than young birds. These observations are in line with previous study, who stated the significant $(\mathrm{p}<0.05)$ difference between adult and young rock pigeon ectoparasites prevalence (Adang et al., 2008). The frequent exposure of adult birds with polluted environments might be one of possible reasons for higher infestation rate.

In current study, prevalence of ectoparasites was more prone to the weak birds as compared to the healthy birds. This might be due to higher susceptibility of weak birds for parasitic host. In current study female rock pigeon were more often infected when related to male birds. Comparable, results were described from south-east region in Punjab, Pakistan (Ahmed et al., 2017). However, no significant difference of ectoparasites was observed between male and female rock pigeons in Nigeria (Adang et al., 2008).

During current study the wings and tail had abundant number of parasites while very small numbers of parasites were present in head, rump and nape feathers as well as chest feathers. Comparable findings were reported from south-east region of Punjab, Pakistan (Ahmed et al., 2017). The results revealed that sampling site, season and age are the important factors.

It is concluded that the rock pigeons were heavily infected with multiple ectoparasites species in Punjab, Pakistan. Although, we have only determined the prevalence of ectoparasites related to rock pigeon in Pakistan; which is relatively more abundant as compared to other wild birds. There is a need to investigate ectoparasites' prevalence in other wild birds. The determination of vector-borne diseases transmitted by these ectoparasites is highly recommended. Furthermore, the study provides preliminary data for the control of ectoparasites in rock pigeons to reduce the load of ectoparasites in domesticated birds and human beings. 


\section{Acknowledgements}

The author thankful to Dr. Haroon Akbar for assistance for identification of ectoparasites.

\section{References}

ABDULLAH, S.H., MOHAMMED, A.A. and SAEID, N.M., 2018. Study of ecto and haemo parasites in domestic pigeons (Columba livia domestica) in Sulaimani province, Kurdistan region/Iraq. Journal of Zankoy Sulaimani - Part A, vol. 20, no. 1, pp. 37-44. http://dx.doi.org/10.17656/jzs.10640.

ADANG, K.L., ONIYE, S.J., EZEALOR, A.U., ABDU, P.A. and AJANUSI, O.J., 2008. Ectoparasites of domestic pigeon (Columba livia domestica, Linnaeus) in Zaria, Nigeria. Research Journal of Parasitology, vol. 3, no. 2, pp. 79-84. http://dx.doi.org/10.3923/jp.2008.79.84.

AHMED, H., NAZ, M., MUSTAFA, I., KHAN, M.R., ASIF, S., AFZAL, M.S., ARSHAD, M., NAVEED, M., ALI, S. and SIMSEK, S., 2017. Impact of epidemiological factors on the prevalence, intensity and distribution of ectoparasites in pigeons. Journal of Parasitic Diseases: Official Organ of the Indian Society for Parasitology, vol. 41, no. 4, pp. 1074-1081. http://dx.doi.org/10.1007/s12639-0170936-0. PMid:29114144.

ALKHARIGY, F.A., EL NAAS, A.S. and EL MAGHRBI, A.A., 2018. Survey of parasites in domestic pigeons (Columba livia) in Tripoli, Libya. Open Veterinary Journal, vol. 8, no. 4, pp. 360-366. http://dx.doi. org/10.4314/ovj.v8i4.2. PMid:30425959.

ARIJO, A.G., MALHI, A.K., AKHTER, N., LAGHARI, Z.A. and MALHI, M.C., 2018. Prevalence of lice infestation in domestic pigeon Columba Livia Domestica in South-Eastern Pakistan. University of Sindh Journal of Animal Sciences, vol. 2, no. 2, pp. 24-29.

BORA, S., 2017. Ectoparasites of poultry in Kamrup district of Assam: an exploratory investigation. Khanapara, Guwahati: College of Veterinary Science, Assam Agricultural University. Doctoral Dissertation.

BUSH, S.E., VILLA, S.M., ALTUNA, J.C., JOHNSON, K.P., SHAPIRO, M.D. and CLAYTON, D.H., 2019. Host defense triggers rapid adaptive radiation in experimentally evolving parasites. Evolution Letters, vol. 3, no. 2, pp. 120-128. http://dx.doi.org/10.1002/evl3.104. PMid:31007943.

CHAECHI-NOSRATI, M.R., ESLAMI, A., RAHBARI, S., HOUSHMAND, E. and YOUSEFI, A., 2018. The survey of parasitic infections of wild pigeons (Columba livia) in Lahijan city, Guilan, Iran. Comparative Clinical Pathology, vol. 27, no. 5, pp. 1405-1408. http://dx.doi.org/10.1007/s00580-018-2779-1.

CHAUDHRY, Q.U.Z., 2017. Climate change profile of Pakistan. Philippines: Asian Development Bank.

DJELMOUDI, Y., MILLA, A., DAOUDI-HACINI, S. and DOUMANDJI, S., 2017. Ectoparasites of Wild Rock Pigeon (Columba Livia Livia) In the Algiers Sahel, Algeria. Advances in Environmental Biology, vol. 11, no. 8, pp. 39-46.

GALLOWAY, T.D. and LAMB, R.J., 2015. Seasonal population dynamics of four species of chewing lice (Phthiraptera: Menoponidae, Philopteridae) on feral pigeons (Aves: Columbiformes: Columbidae). Canadian Entomologist, vol. 147, no. 6, pp. 712722. http://dx.doi.org/10.4039/tce.2014.84.

JAHANTIGH, M., ESMAILZADE DIZAJI, R. and TEYMOORI, Y., 2016. Prevalence of external parasites of pigeon in Zabol, southeast of Iran. Journal of Parasitic Diseases: Official Organ of the Indian Society for Parasitology, vol. 40, no. 4, pp. 1548-1551. http:// dx.doi.org/10.1007/s12639-015-0725-6. PMid:27876980.

JEZKOVA, T. and WIENS, J.J., 2017. What explains patterns of diversification and richness among animal phyla? American
Naturalist, vol. 189, no. 3, pp. 201-212. http://dx.doi. org/10.1086/690194. PMid:28221832.

PRICE, R.D., HELLENTHAL, R.A., PALMA, R.L., JOHNSON, K.P. and CLAYTON, D.H., 2003. The chewing lice: world checklist and biological overview. Urbana: Illinois Natural History Survey. Special Publication, no. 24.

KOLOMAK, I.O. and KRUCHYNENKO, O.V., 2017. Bird lice (Mallophaga, Philopteridae, Menoponidae) of domestic pigeons on specialized pigeon breeding farms in Poltava. Vestnik Zoologii, vol. 51, no. 6, pp. 487-492. http://dx.doi.org/10.1515/vzoo-2017-0058.

LAKU, C.B., ONWUTEAKA, J.N. and AMUZIE, C.C., 2018. Ecto-parasites and intestinal helminth community of domesticated pigeons (Columba livia) of Trans-Amadi abattoir, Port Harcourt, Nigeria. Journal of Gastroenterology Forecast, vol. 1, no. 2, pp. 1010.

MARGOLIS, L., ESCH, G.W., HOLMES, J.C., KURIS, A.M. and SCHAD, G., 1982. The use of ecological terms in parasitology (report of an ad hoc committee of the American Society of Parasitologists). The Journal of Parasitology, vol. 68, no. 1, pp. 131-133. http:// dx.doi.org/10.2307/3281335.

MEHMOOD, S., NASHIRUDDULLAH, N., AHMED, J.A. and BORKATAKI, S., 2019. Parasitic affections of domesticated pigeons (Columba livia) in Jammu, India. Annals of Parasitology, vol. 65, no. 1, pp. 53-64. PMid:31127877.

MUSA, S., AFROZ, S.D. and KHANUM, H., 2011. Occurrence of ectoand endoparasites in pigeon (Columba livia Linn.). University Journal of Zoology. Rajshahi University, vol. 30, pp. 73-75. http:// dx.doi.org/10.3329/ujzru.v30i0.10758.

MUSA, S., RAHMAN, T. and KHANUM, H., 2012. Prevalence and intensity of parasites in domestic ducks. Dhaka University Journal of Biological Sciences, vol. 21, no. 2, pp. 197-199. http:// dx.doi.org/10.3329/dujbs.v21i2.11518.

NAZ, S., SYCHRA, O. and RIZVI, S.A., 2012. New records and a new species of chewing lice (Phthiraptera, Amblycera, Ischnocera) found on Columbidae (Columbiformes) in Pakistan. ZooKeys, vol. 174, pp. 79-93. http://dx.doi.org/10.3897/zookeys.174.2717. PMid:22451786.

NYLIN, S., AGOSTA, S., BENSCH, S., BOEGER, W.A., BRAGA, M.P., BROOKS, D.R., FORISTER, M.L., HAMBÄCK, P.A., HOBERG, E.P., NYMAN, T., SCHÄPERS, A., STIGALL, A.L., WHEAT, C.W., ÖSTERLING, M. and JANZ, N., 2018. Embracing colonizations: a new paradigm for species association dynamics. Trends in Ecology E' Evolution, vol. 33, no. 1, pp. 4-14. http://dx.doi. org/10.1016/j.tree.2017.10.005. PMid:29113696.

RANI, M.P.B.R. and RAJAKUMARI, D.S., 2020. A study of parasites in domestic pigeons (Columba livia) in Tirunelveli District, Tamilnadu. Studies in Indian Place Names, vol. 40, no. 70, pp. 3022-3036.

REZAEI, F., HASHEMNIA, M., CHALECHALE, A., SEIDI, S. and GHOLIZADEH, M., 2016. Prevalence of ectoparasites in freerange backyard chickens, domestic pigeons (Columba livia domestica) and turkeys of Kermanshah province, west of Iran. Journal of Parasitic Diseases: Official Organ of the Indian Society for Parasitology, vol. 40, no. 2, pp. 448-453. http://dx.doi. org/10.1007/s12639-014-0524-5. PMid:27413319.

SAIKIA, M., BHATTACHARJEE, K., SARMAH, P.C., DEKA, D.K. and MUSHAHARY, D., 2017. Prevalence of ectoparasitic infestation of pigeon (Columba livia domestica) in Assam, India. Journal of Entomology and Zoology Studies, vol. 5, no. 4, pp. 1286-1288.

TENDEIRO, J., 1969. Estudos sobre os Goniodídeos (Mallophaga, Ischnocera) dos Columbiformes. I. Género Nitzschiella Kéler, 1939. Separata de Revista de Ciéncias Veterinárias, vol. 2, pp. 1-124.

WALTHER, B.A. and CLAYTON, D.H., 1997. Dust-ruffling: a simple method for quantifying ectoparasite loads of live birds. Journal of Field Ornithology, vol. 68, no. 4, pp. 509-518. 